\title{
ADDITIONS TO THE CHECK-LIST OF BIRDS OF THE ADDO ELEPHANT NATIONAL PARK
}

\section{B. L. PENZHORN and P. F. VAN STRAATEN}

Addo Elephant National Park

Private Bag X6027

Port Elizabeth

6000

In his original check-list of the birds of the Addo Elephant National Park, Liversidge (1965) recorded 120 species. In a subsequent publication six additional species were reported from the Park (Penzhorn and Morris 1969). A further seven species are reported here, increasing the species total for the Park to 133 .

The seven additional species recorded are listed below. The numbers denote those used by McLachlan and Liversidge (1957) in Roberts birds of South Africa and the nomenclature follows the Check list of the birds of South Africa (S.A.O.S. List Committee 1969).

47 WHITE-BREASTED CORMORANT WITBORSDUIKER

Phalacrocorax lucidus (Lichtenstein) White-breasted cormorants were first reported from Caesar's Dam by Lockhart (1968a) in July 1967. They have subsequently been recorded regularly at the Dam.

52 AFRICAN DARTER SLANGHALSVOËL

Anhinga rufa (Lacépède et Daudin)

Three darters were seen at Caesar's Dam by Lockhart (1968b) in July 1967.

133 BLACK EAGLE WITKRUISAREND

Aquila verreauxi Lesson

A single bird was seen soaring above the elephant enclosure in June 1972. This was probably a vagrant from the Suurberg range north of the Park where black eagles are resident (Skead 1967).

343 RED-CHESTED CUCKOO Cuculus solitarius Stephens PIET-MY-VROU

Red-chested cuckoos have infreqeuntly been heard calling during the early summer months.

352 DIDRIC CUCKOO Chrysococcyx caprius (Boddaert) DIEDRIKKIE

Didric cuckoos have frequently been heard calling during the summer months. 
356 BURCHELL'S COUCAL

Centropus superciliosus Hemprich VLEILOERIE

and Ehrenberg

These coucals have been seen among the reeds and rushes at Caesar's Dam and heard calling at the small dam east of the Nature Conservator's house.

373 FIERY-NECKED NIGHTJAR SUID-AFRIKAANSE NAGUIL

Caprimulgus pectoralis Cuvier

The calls of these nightjars have infrequently been heard on moonlit nights.

Liversidge (1965) predicted that his total of 120 species of birds would be increased, "particularly in respect to birds of the habitats in and around Caesar's Dam". Of the 13 species subsequently reported, six were recorded at the Dam.

\section{REFERENCES}

LIVERSIDGE, R. 1965. The birds of the Addo National Park. Koedoe 8: 41-67.

LOCKHART, P. S. 1968a. New distributional data: 1. White-breasted cormorant. Ostrich 39:271.

LOCKHART, P. S. 1968b. New distributional data: 1. African darter. Ostrich 39:271.

McLACHLAN, G. R. and R. LIVERSIDGE. 1957. Roberts birds of South Africa. 2nd ed. Cape Town: Trustees of the S.A. Bird Book Fund.

PENZHORN, B. L. and A. K. MORRIS. 1969. A supplementary checklist of the birds recorded in the Addo Elephant National Park. Koedoe 12:106-107.

S.A.O.S. LIST COMMITTEE. 1969. Check list of the birds of South Africa. Cape Town: South African Ornithological Society.

SKEAD, C. J. 1967. Ecology of birds in the Eastern Cape Province. Ostrich Suppl. 7:1-103. 